\title{
Sarcosine Oxidase Activity of Rat Liver Tissue : Effect of Folic Acid Deficiency and Induced Hyperthyroidism
}

\author{
Marian E. Swendseid, Ann L. Swanson and Frank H. Bethell \\ From the Thomas Henry Simpson Memorial Institute for Medical Research, \\ University of Michigan, Ann Arbor, Michigan
}

Received June 5, 1952

\section{INTRODUCTION}

Experimental evidence linking the vitamins, folic acid and $B_{12}$, to methyl group metabolism has been obtained in bacterial, mammalian, and avian species $(1,2)$. The role of the folic acid group of vitamins in the metabolism of 1-carbon intermediates has been placed on a definitive basis through isotopic studies involving formate transfer (3-6), whereas the participation of vitamin $B_{12}$ in the same metabolic area has remained more obscure (2).

In regard to the actual enzymes with which these two vitamins can be presumed to be associated, present knowledge is extremely limited. Oginsky ( 7 ) found that liver tissue from $\mathrm{B}_{12}$-deficient rats was relatively incapable of carrying out the enzymic transfer of methyl groups from choline or betaine to homocystine. Buchanan (8), studying the exchange of formate carbon with inosinate as catalyzed by a cell-free pigeon liver homogenate, found an increase in rate of transfer on addition of citrovorum factor, a metabolic analog of folic acid.

Sarcosine, a metabolite of betaine in the rat (9), has been shown by Mackenzie (10) and by Handler and co-workers (11) to be oxidatively demethylated to formaldehyde and glycine in rat liver homogenates. Since this enzymic reaction occurs in the metabolic area where folis acid and vitamin $B_{12}$ are believed to function, and since the enzyme involved, sarcosine oxidase, can be quantitated, it was decided in this present study to measure the sarcosine oxidase activity in the hepatic tissue of rats maintained on diets producing deficiencies of these vitamins. It has been found that under the experimental conditions employed, liver tissue from Aminopterin- ${ }^{-1}$ or Sulfasuxidine-treated rats has

1 We wish to express our appreciation to Dr. J. M. Reugsegger of Lederle Laboratories for generous supplies of this material. 
a sarcosine oxidase content similar to that of normal controls, whereas liver tissue from rats maintained on an iodinated casein-supplemented diet is much lower in sarcosine oxidase activity.

\section{MeTHODS}

\section{Production of a Folic Acid Deficiency}

Male weanling rats in groups of six animals were maintained on an $18 \%$ caseindextrose diet supplemented with synthetic vitamins (12). In one series of experiments, $2 \%$ Sulfasuxidine was added to the diet and in another, $0.5 \mathrm{mg} . / \mathrm{kg}$. Aminopterin. Leukocyte counts on the peripheral blood of these rats were made at intervals and the appearance of granulocytopenia was taken as evidence that. a folie acid deficiency state had developed (13). This usually occurred in a 6-week period on the Sulfasuxidine diet and in a 2 -week period on the diet containing Aminopterin.

\section{Production of a Vitamin $B_{12}$ Deficiency}

Male weanling rats in groups of six animals were placed on the diet of Frost et al. (14). This diet, which contains iodinated casein at a level of $0.5 \%$, is presumed to increase the metabolism of the rat with a resultant increase in the $B_{12}$ requirement. As in the experiments reported, the rats on the iodinated casein diet gained less weight than the normal controls, a condition that was partially corrected by the dietary addition of vitamin $B_{12}$.

\section{Determination of Sarcosine Oxidase Activity}

Liver tissues from several animals of a given experimental group were pooled for each determination. The tissue was homogenized by the Potter-Elvehjem technique in four parts of $0.067 M(M / 15)$ phosphate buffer, $\mathrm{pH}$ 7.8. The sarcosine oxidase content of these livers was determined by the method of Mackenzie (10) wherein the homogenate is first centrifuged and the enzyme activity of the residue determined manometrically. The quantities used in the Warburg flask were $2 \mathrm{ml}$. of a 1:5 suspension of the liver residue in phosphate buffer at $\mathrm{pH} 7.8$ and $0.5 \mathrm{mg}$. sarcosinc. The results, as obtaincd in a scrics of control experiments, were quite reproducible. The endogenous $\mathrm{O}_{2}$ uptake was extremely low under these circumstances, but it is subtracted from total $\mathrm{O}_{2}$ uptake figures in determining the sarcosine oxidase activity. The values for enzymic activity are reported in terms of $\mathrm{QO}_{2}(\mathrm{~N})$, the $\mu \mathrm{l}$. $\mathrm{O}_{2}$ consumed $/ \mathrm{hr} . / \mathrm{mg}$. of liver residue nitrogen. Nitrogen was determined by the method of Koch and MeMeekin (15).

\section{Results}

Measurements of the sarcosine oxidase content of the liver tissue from rats made deficient in folic acid through the feeding of either Sulfasuxidine or Aminopterin has shown that the activity of this enzyme is identical with that obtained in normal hepatic tissue. The 
results are given in Table I. It can be concluded that the enzyme concerned in the production of formaldehyde or formate by the oxidative

\section{TABLE I}

Sarcosine Oxidase Activity of Liver Tissue from Normal and Folic Acid-

Deficient Rats

\begin{tabular}{l|c|c|c}
\hline Expt. No. & Dietary method for producing folic acid deficiency & \multicolumn{2}{|c}{ Liver sarcosine oxidase } \\
\cline { 3 - 4 } & & Control rats & $\begin{array}{c}\text { Folic acid- } \\
\text { deficient rats }\end{array}$ \\
\hline & & $Q_{O_{2}}(N)$ & $Q_{O_{2}}(N)$ \\
2 & Basal ration and sulfasuxidine $(20 \mathrm{~g} . / \mathrm{kg})$. & 14.0 & 13.5 \\
3 & & 10.3 & 10.6 \\
\hline 4 & Basal ration and aminopterin $(0.5 \mathrm{mg} . / \mathrm{kg})$. & 12.2 & 11.7 \\
\hline 5 & & 11.5 & 13.0 \\
\hline 6 & & 14.5 & 11.9 \\
\hline
\end{tabular}

TABLE II

Sarcosine Oxidase Activity of Liver Tissue from Rats Maintained on a Diet Containing Iodinated Casein

\begin{tabular}{|c|c|c|c|c|}
\hline Expt. No. & & Diet supplement & $\begin{array}{c}\text { Expt. Time } \\
\text { Days }\end{array}$ & $\begin{array}{c}\text { Liver sarcosine } \\
\text { oxidase } \\
Q_{\mathrm{O}_{2}}(\mathrm{~N})\end{array}$ \\
\hline 1 & $\begin{array}{c}\text { Basal } \\
" \\
"\end{array}$ & $\begin{array}{l}+\mathrm{I}_{2} \text { casein }(5 \mathrm{~g} . / \mathrm{kg} .) \\
+\mathrm{I}_{2} \text { casein }(5 \mathrm{~g} \cdot / \mathrm{kg} .)\end{array}$ & and $B_{12}(100 \mu g . / k g)$. & $\begin{array}{l}8.6 \\
2.9 \\
3.6\end{array}$ \\
\hline 2 & $\underset{*}{\text { Basal }}$ & $+I_{2}$ casein & 14 & $\begin{array}{r}15.6 \\
6.1\end{array}$ \\
\hline 3 & $\underset{*}{\text { Basal }}$ & $+I_{2}$ casein & 21 & $\begin{array}{r}14.9 \\
5.2\end{array}$ \\
\hline 4 & 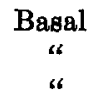 & $\begin{array}{l}+I_{2} \text { casein } \\
+I_{2} \text { casein and } B_{12}\end{array}$ & 28 & $\begin{array}{r}15.5 \\
5.4 \\
6.2\end{array}$ \\
\hline
\end{tabular}

demethylation of sarcosine is not dependent for its activity upon the presence of the folic acid group of vitamins.

Experiments with hepatic tissue from rats maintained on an iodinated casein-supplemented diet have shown that the sarcosine oxidase content is much reduced as compared with values in normal rat liver tissue. 
Table II shows that $Q_{o_{2}}(\mathrm{~N})$ values for liver sarcosine oxidase in iodinated casein-fed rats are approximately $30 \%$ of values for control rat livers. These values were obtained in four separate consecutive feeding experiments and are typical of the results in a total of nine feeding experiments. The decrease in sarcosine oxidase occurs early in the experimental period and the enzyme activity then remains at a relatively constant level. As is also reported in Table II, supplementation of the diet with vitamin $B_{12}(100 \mu \mathrm{g} . / \mathrm{kg}$. of diet $)$ fails to increase the sarcosine oxidase activity to normal levels. Hence, it must be concluded either that the lowered sarcosine oxidase activity obtained by feeding iodinated casein is not directly attributable to a vitamin $B_{12}$ deficiency, or that lack of this vitamin influences the enzyme activity in an irreversible manner.

\section{Discussion}

The experiments of Sakami and Welch (5) and Plaut and associates (3) have shown that the rate of formate utilization for methyl group synthesis is dependent upon the presence of folic acid. If sarcosine can be taken as a typical example of compounds which contribute to the "formate pool" through oxidative demethylation, then it is suggested that folic acid does not function in enzyme systems concerned with the breakdown of the methyl group to give formate.

The association of a decreased sarcosine oxidase activity with hyperthyroidism in rats has been demonstrated in these experiments. These results suggest that methylation processes in hyperthyroid states should be studied in more detail. Since no direct evidence could be obtained that a vitamin $B_{12}$ deficiency was the primary cause of the lowered sarcosine oxidase activity, further experiments on the possible relationship of sarcosine oxidase and vitamin $\mathrm{B}_{12}$ are being carried out.

\section{Summary}

The sarcosine oxidase content of hepatic tissue from rats made deficient in folic acid was similar to that of normal rats. This is taken as evidence that sarcosine oxidase activity is not dependent upon the presence of folic acid vitamins.

The liver sarcosine content of vitamin $B_{12}$-deficient rats was decreased below normal values. Since $B_{12}$ supplementation did not increase the enzyme activity, it could not be ascertained whether the loss in enzyme activity was primarily due to a $\mathrm{B}_{12}$ deficiency or whether it was the result of other conditions imposed by a hyperthyroid state. 


\section{REFERENCES}

1. Jukes, T. H., and Storstad, E. L. R., Vitamins and Hormones. Academic Press, New York, 1951.

2. Weich, A. D., ANd Heinle, R. W., Pharmacol. Revs. 3, 345 (1951).

3. Piaut, G. W. E., Betheil, J. J., a.vi Lardy, H. A., J. Biol. Chem. 184, 795 (1950).

4. Elwyn, D., And Sprinson, D. B., J. Biol. Chem. 184, 475 (1950).

5. Sakami, W., and Welch, A. D., J. Biol. Chem. 187, 279 (1950).

6. Totter, J. R., Kell.ey, B., Day, P. L., and Edwards, R. R., J. Biol. Chem. 186, $145(1950)$.

7. OGINSky, E. L., Arch. Biochem. 26, 327 (1950).

8. Buchaxas, J. M., Abstracts Am. Chem. Soc., p. 13. 119th Meeting, 1951, Boston, Mass.

9. Horver, W. H., A.vd Mackenzie, C. G., J. Biol. Chem. 187, 15 (1950).

10. Mackenzif, C. G., J. Biol. Chem. 186, 351 (1950).

11. Handler, P., Bernieim, M. L. C., and Kleis, J. R., J. Biul. Chem. 139, 211 (1941).

12. Swendseid, M. E., Bhown, R. A., Bird, O. D., and Heistich, R., Arch. Biochem. 16, 367 (1948).

13. Daft, F. H., and Sebreli, W. H., Pub. Health Repts. U. S. Pub. Health Sert ice 68, 1542 (1943).

14. Frost, D. V., Fricke, H. H., a.di Spruti, H. C., Proc. Soc. Exptl. Biol. Med. 72, $102(1949)$.

15. Koch, F. C., And McMeekix, T. L., J. Am. Chem. Soc. 46, 2066 (1924). 